\title{
Structural and Productive Characteristics of Urochloa Cultivars Submitted to Different Defoliation Frequencies in Semiarid Region
}

\author{
Jacqueline dos Santos Oliveira \\ Animal Science Department, Federal University of Lavras, Brazil \\ João Virgínio Emerenciano Neto (Corresponding Author), Rodrigo da Silva Santos, Breno \\ Ramon de Souza Bonfim, Fábio Nunes Lista, Vanessa Alexandre Vieira \\ Agricultural Science Campus, Federal University of São Francisco Valley, Petrolina, Brazil \\ Gelson dos Santos Difante \\ Faculty of Veterinary Medicine and Animal Science, Federal University of Mato Grosso do \\ Sul, Campo Grande, Brazil
}

Received: August 1, 2019 Accepted: August 6, 2019 Published: August 8, 2019

doi:10.5296/jas.v7i3.15177～URL: https://doi.org/10.5296/jas.v7i3.15177

\begin{abstract}
This study assessed the effect of three cutting intervals (30, 45 and 60 days) on structural and production features of five different cultivars (Urochloa Brizantha: Marandu, Piatã and Xaraés; Urochloa decumbens: Basilisk; Urochloa hybrid: Mulato I). The experiment was carried out in a completely randomized design. The interaction between the defoliation frequency and the cultivars not significant to the length and width of the leaf blade, the diameter of the stem, and the number of living leaves. There was no effect of the cutting intervals on the width of the leaf blade, and the number or living leaves. The length and width of the leaf blade were highest in the Xaraés grass. The diameter of the stem, the height canopy and the forage mass grew as a function of the cutting interval. Cv. Xaraés displayed the highest heights and was the most productive. Stems and leaves masses, and the accumulation rates grew with the increase of the cutting intervals. The ratio leaf blade stem decreased as increasing the cutting intervals. Urochloa pastures should be handled with defoliation frequencies up to 45 days. $\mathrm{Cv}$. Xaraés displays a high dry matter production and we suggest its use in intensive production systems.
\end{abstract}

Keywords: canopy height, cutting intervals, dry matter production, forage accumulation, morphological composition 


\section{Introduction}

Pastures represent the primary source of feeds in the production of meat and dairy cattle in Brazil. It is an efficient, and cheap form of feeding for the breeders, as about $90 \%$ of the nutrients derive directly form grazing in Brazil (Euclides et al. 2010). Even the same, proper handling of the pasture is crucial, in order to use it frequently. The proper handling of pasture requires a minimal quantity of residual after cutting or stocking. In this form the grass shall regrow quickly, with minimal use of its reserves, avoiding the exhaustion of the plants. The low grazing pressure and low frequency of defoliation may cause qualitative and quantitative losses in the forage, for the excessive accumulation of stem, and the excess of senescent material. On the other side, high grazing pressure may reduce the reserves of the pasture dramatically, reducing its persistence (Cutrim Júnior et al. 2010).

One of the critical elements of pasture handling is the regrowth, id est the interval between subsequent cuttings. Regrowth time cannot be too long, in order to avoid those processes that reduce the nutritive value, and the structural features of the canopy (Alexandrino et al. 2005). According to Silva \& Nascimento Júnior (2007), the analysis of the structural, morphogenic, and productive features of the pasture (height, forage mass, leaves blades mass, Leaf Area Index - LAI, and so forth) became a crucial tool to assess the status of the pasture, that aim to guarantee sustainable animal production under pasture management.

Cultivars of the Genus Urochloa highlighted, due to their adaptability to acid, and low fertility soils, their simple setting through seeding, higher flexibility to stocking management, and higher animal performance, as compared with native species of forage (Santos et al. 2011). As considering what we presented so far, this article aimed to assess the effect of different cutting intervals on structural and productive features of five different varieties of Urochloa.

\section{Materials and Methods}

\subsection{Site Description}

The experiment was carried out in Agricultural Sciences Campus, of the Federal University of the Vale do São Francisco, located in Petrolina, Pernambuco, Brazil (09¹9'S, 40³3'W). According to the Köppen classification, the climate is of BSh type, with an average annual temperature of $26^{\circ} \mathrm{C}$ and average annual precipitation of $435 \mathrm{~mm}$. Precipitation and temperature data (Fig. 1) were collected at a meteorological station located $50 \mathrm{~m}$ from the experimental area. The soil at the experimental area is a Yellow Argissoil, with medium/sandy texture (EMBRAPA, 2006). Before the beginning of the experiment, soil samples were collected in the 0-0.2 m layer, whose chemical attributes are described in Table 1. Fertilization was done only with urea, using $150 \mathrm{~kg} \mathrm{ha}^{-1}$ year $^{-1} \mathrm{~N}$, divided into three applications, one for every two evaluation cycles. 


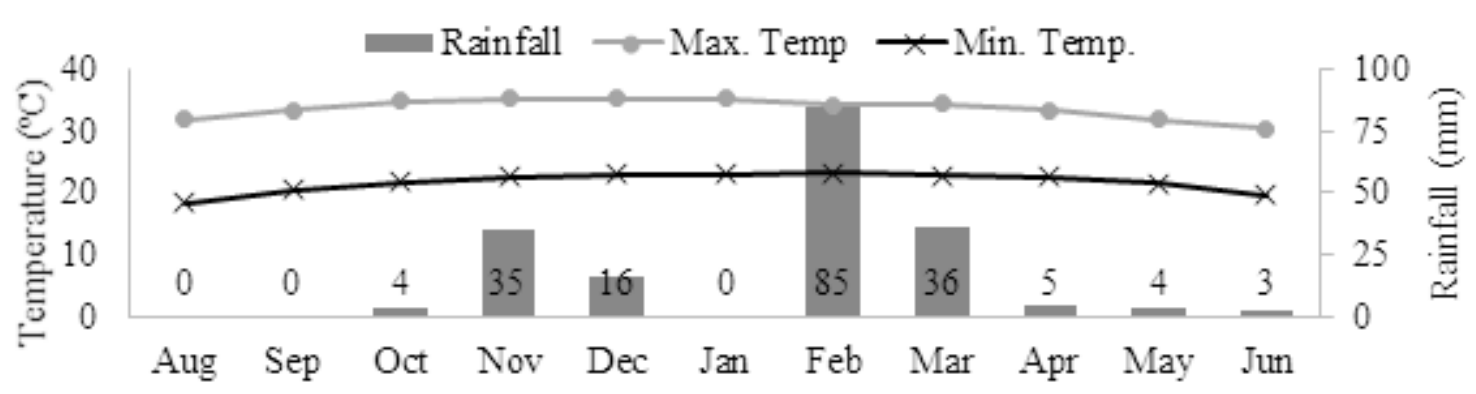

Figure 1. The Trend of Economic Development Description for the above figure

Table 1. Soil chemical characteristics from the experimental area in the $0-20 \mathrm{~cm}$ layer

\begin{tabular}{|c|c|c|c|c|c|c|c|c|c|}
\hline \multirow{2}{*}{$\begin{array}{r}\mathrm{pH} \\
\mathrm{H}_{2} \mathrm{O} \\
\end{array}$} & \multirow{2}{*}{$\begin{array}{c}\mathrm{P} \\
\left(\mathrm{mg} \mathrm{dm}^{-3}\right)\end{array}$} & $\mathrm{Ca}$ & $\mathrm{Mg}$ & K & $\mathrm{Na}$ & $\mathrm{H}+\mathrm{Al}$ & $\mathrm{Al}$ & CEC & \multirow{2}{*}{$\begin{array}{l}\text { BS } \\
(\%)\end{array}$} \\
\hline & & \multicolumn{7}{|c|}{$\left(\mathrm{cmol}_{\mathrm{c}} \mathrm{dm}^{-3}\right)$} & \\
\hline 5.7 & 20.22 & 1.5 & 0.8 & 0.36 & 2.17 & 1.16 & 0.0 & 5.98 & 81 \\
\hline
\end{tabular}

CEC: cation exchange capacity; BS: Base saturation

The beds of Urochloa were established via vegetative propagation in September of 2015. From then on, the plants were managed with cuts every 30 days, and the area was maintained weed-free. Irrigation was performed by micro-sprinkling, five times a week, during the entire field cropping. Before starting the evaluations, a standardization cut was made on the plants in all experimental units, cutting them $25 \mathrm{~cm}$ from the soil surface.

The treatments consisted of five cultivars of Urochloa: Marandu, Piatã and Xaraés ( $U$. brizantha); Basilisk (U. decumbens); and the hybrid Mulato (U. decumbens x U. ruziziensis), under different defoliation frequencies (30, 45 and 60 days). The cut intensity was $0.25 \mathrm{~m}$ of residue height for all treatments (Emerenciano Neto et al. 2013). The useful area of each experimental unit was $2.5 \mathrm{~m}^{2}(2.5 \times 1.0 \mathrm{~m})$, with three units for each treatment.

\subsection{Evaluated Characteristics}

The height of the canopy was determined with a graduated rod and was considered from the ground level to the average curvature of the leaves. Then, the plants contained in the plot area $\left(2.5 \mathrm{~m}^{2}\right)$ were cut, and the total forage mass was determined. Afterward, samples of approximately $0.20 \mathrm{~kg}$ were collected, which were manually separated into leaves and stems. These samples were weighed and sent to a greenhouse with forced air circulation, at $55^{\circ} \mathrm{C}$ for 72 hours, to determine the dry matter content.

From the dry matter contents, the total forage and morphological components were estimated ( $\left.\mathrm{kg} \mathrm{ha}^{-1} \mathrm{DM}\right)$ and leaf blade stem ratio were estimated, by the ratio between dry leaf blade mass and dry mass of the stem. The total forage, leaf blade, and stem accumulation rates were calculated by the ratio between the respective masses and the regrowth periods (30, 45 and 60 days), expressed in $\mathrm{kg} \mathrm{ha}^{-1} \mathrm{day}^{-1} \mathrm{DM}$.

The length and width of the leaf blade, stem diameter, and the number of live leaves were determined in three representative tillers of each treatment. The length and width were measured in the last expanded leaf of the tiller, using a digital caliper. The length of the leaf blade was considered from the end of the leaf to its ligule. The width was measured in the 
central part of the leaf blade, and the diameter of the stem was determined in the middle of this component. In order to determine the number of live leaves, the expanding and expanded leaves of each tiller were considered, excluding those that presented more than $50 \%$ of the senescent blade, which were considered as dead.

\subsection{Statistical Analysis}

The experimental design was completely randomized, with a scheme of measures repeated in time (cuts) and three replicates. Data were submitted to analysis of variance, and the means of the treatments and the effect of the interaction were compared by the Tukey test at 5\% probability ( $p \leq 0.05$ ), using the statistical program SISVAR 5.6 (Ferreira, 2011).

\section{Results}

The interaction between the cutting intervals and the cultivars was not significant $(p>0.05)$ for the length and width of the leaf blade, stem diameter, and the number of live leaves. The length of the leaf blade was affected $(p<0.05)$ by the cutting intervals and increased as increasing the interval between the cuttings. We observed the highest values at 45 and 60 days of regrowth (Table 2).

Table 2. Leaf blade length and width, stem diameter and number of live leaves under different defoliation frequencies

\begin{tabular}{lcccc}
\hline \multirow{2}{*}{\multicolumn{1}{c}{ Variables }} & \multicolumn{3}{c}{ Defoliation frequency (day) } & \multirow{2}{*}{ SEM } \\
\cline { 2 - 4 } & 30 & 45 & 60 & \\
\hline Leaf blade length $(\mathrm{cm})$ & $31.38^{\mathrm{b}}$ & $38.32^{\mathrm{ab}}$ & $42.42^{\mathrm{a}}$ & 2.50 \\
Leaf blade width (cm) & $1.90^{\mathrm{a}}$ & $2.05^{\mathrm{a}}$ & $1.94^{\mathrm{a}}$ & 0.09 \\
Stem diameter (cm) & $0.44^{\mathrm{b}}$ & $0.45^{\mathrm{ab}}$ & $0.53^{\mathrm{a}}$ & 0.03 \\
Number of live leaves (leaves tiller $\left.{ }^{-1}\right)$ & $4.55^{\mathrm{a}}$ & $5.03^{\mathrm{a}}$ & $4.80^{\mathrm{a}}$ & 0.26 \\
\hline
\end{tabular}

SEM (standard error of mean). Means followed by distinct letters in the line differ from one another by Tukey test $(\mathrm{P}<0.05)$.

The width of the leaf blade and the number of live leaves did not differ $(p>0.05)$ according to the cutting intervals. The average values observed were of $1.96 \mathrm{~cm}$ and 4.79 leaves tiller $^{-1}$, respectively. On the other side, the regrowth period influenced the stem diameter $(p<0.05)$. At 60 days of regrowth, the stem diameter was higher than at 30 days. The difference between the stem diameter assessed at 45 and 60 days was not significant. (Table 2).

As refers to cultivars, we observed a significant difference $(p<0.05)$ for the length and width of the leaf blade, stem diameter, and the number of live leaves. Cultivar Xaraés displayed higher length and width of the leaf blade as compared with cv. Basilisk. We observed the lowest stem diameter in the cv. Basilisk. The other cultivars did not differ significantly among each other. On the other side, the number of live leaves was higher in the cv. Basilisk as compared with the cvs. Marandu and Xaraés, but did not differ from the cultivars cvs. Mulato I e Piatã (Table 3). 
Table 3. Leaf blade length and width, stem diameter and number of live leaves in Urochroa cultivars

\begin{tabular}{lcccccc}
\hline \multirow{2}{*}{\multicolumn{1}{c}{ Variables }} & \multicolumn{5}{c}{ Cultivar } & \\
\cline { 2 - 7 } & Basilisk & Marandu & Mulato I & Piatã & Xaraés \\
\hline Leaf blade length $(\mathrm{cm})$ & $21.60^{\mathrm{c}}$ & $38.48^{\mathrm{b}}$ & $34.59^{\mathrm{b}}$ & $39.70^{\mathrm{b}}$ & $51.41^{\mathrm{a}}$ & 2.03 \\
Leaf blade width (cm) & $1.56^{\mathrm{c}}$ & $1.83^{\mathrm{bc}}$ & $2.12^{\mathrm{ab}}$ & $1.86^{\mathrm{bc}}$ & $2.36^{\mathrm{a}}$ & 0.08 \\
Stem diameter (cm) & $0.33^{\mathrm{b}}$ & $0.46^{\mathrm{a}}$ & $0.49^{\mathrm{a}}$ & $0.48^{\mathrm{a}}$ & $0.56^{\mathrm{a}}$ & 0.02 \\
Number of live leaves (leaves tiller $\left.{ }^{-1}\right)$ & $5.40^{\mathrm{a}}$ & $4.30^{\mathrm{b}}$ & $4.83^{\mathrm{ab}}$ & $5.10^{\mathrm{ab}}$ & $4.10^{\mathrm{b}}$ & 0.21 \\
\hline
\end{tabular}

SEM (standard error of mean). Means followed by distinct letters in the line differ from one another by Tukey test $(\mathrm{P}<0.05)$.

The interaction between the cutting interval and the cultivars was significant $(p<0.05)$ as refers to the height of the canopy, forage mass, leaf blade mass, stem mass, leaf blade stem ratio, and the accumulation rates of forage, stem, and leaf. At 30 days of regrowth, cv. Xaraés displayed the highest height and cv. Basilisk the lowest. At 45 days of regrowth, we observed no significant difference $(p>0.05)$ among the heights of the pastures of the different studied varieties. We observed the highest heights of pasture at 60 days of cutting interval. The highest values were of the cvs. Xaraés, Piatã, and Mulato I in comparison with cv. Basilisk (Table 4).

Table 4. Canopy height and forage mass in Urochroa cultivars under different defoliation frequencies

\begin{tabular}{cccccc}
\hline \multirow{2}{*}{ Cut interval (day) } & \multicolumn{5}{c}{ Cultivar } \\
\cline { 2 - 5 } & Basilisk & Marandu & Mulato I & Piatã & Xaraés \\
\hline \multicolumn{5}{c}{ Canopy height $(\mathrm{cm})(\mathrm{SEM}=14.41 \%)$} \\
\hline 30 & $36.78^{\mathrm{Bb}}$ & $40.56^{\mathrm{ABb}}$ & $49.05^{\mathrm{ABb}}$ & $43.95^{\mathrm{ABc}}$ & $52.45^{\mathrm{Ac}}$ \\
45 & $63.84^{\mathrm{Aa}}$ & $64.33^{\mathrm{Aa}}$ & $64.5^{\mathrm{Ab}}$ & $72.84^{\mathrm{Ab}}$ & $76.84^{\mathrm{Ab}}$ \\
60 & $64.67^{\mathrm{Ba}}$ & $80.83^{\mathrm{ABa}}$ & $86.83^{\mathrm{Aa}}$ & $94.42^{\mathrm{Aa}}$ & $96.25^{\mathrm{Aa}}$ \\
\hline & & Forage mass & $\left(\mathrm{kg} \mathrm{ha}^{-1} \mathrm{DM}\right)(\mathrm{SEM}=680.13)$ \\
\hline 40 & $1762.13^{\mathrm{Ac}}$ & $2240.85^{\mathrm{Ab}}$ & $1754.42^{\mathrm{Ac}}$ & $3195.04^{\mathrm{Ac}}$ & $3272.84^{\mathrm{Ac}}$ \\
60 & $5152.31^{\mathrm{Bb}}$ & $5135.71^{\mathrm{Ba}}$ & $4268.66^{\mathrm{Bb}}$ & $6225.24^{\mathrm{ABb}}$ & $9367.28^{\mathrm{Ab}}$ \\
\hline & $9464.53^{\mathrm{Ba}}$ & $6605.86^{\mathrm{Ca}}$ & $7581.67^{\mathrm{BCa}}$ & $8845.98^{\mathrm{BCa}}$ & $12255.59^{\mathrm{Aa}}$ \\
\hline
\end{tabular}

SEM (standard error of mean). Means followed by distinct letters, upper case in the row and lowercase in the column, differ by Tukey test $(\mathrm{P}<0.05)$.

We observed the highest mass of forage at the cutting interval of 60 days, intermediate at the 45 days interval, and the lowest at 30 days, independently from the cultivar. Forage mass was similar $(p>0.05)$ among the cultivars at the cutting interval of 30 days, and higher in the cultivar Xaraés at the cutting intervals of 45, and 60 days (Table 4).

We observed the highest leaf blade mass at the cutting intervals of 45 and 60 days. Among 
the studied cultivar, cv. Xaraés pointed out for its leaf blades production at the cutting intervals of 45 and 60 days. At the 30 days intervals, it did not differ from the cvs. Piatã, Marandu, and Mulato. We observed the lowest stem mass at the cutting interval of 30 days, independently from the cultivars ( $p>0.05$ ). Even the same, at the cutting intervals of 45 , and 60 days, cvs. Basilisk and Xaraés displayed the highest stem masses, as compared to the remaining varieties (Table 5).

Table 5. Leaf blade mass, stem mass and leaf blade stem ratio in Urochroa cultivars under different defoliation frequencies

\begin{tabular}{cccccc}
\hline \multirow{2}{*}{$\begin{array}{c}\text { Cut interval } \\
(\text { day })\end{array}$} & Basilisk & Marandu & Mulato I & Piatã & Xaraés \\
\cline { 2 - 5 } & \multicolumn{5}{c}{ Leaf blade mass $\left(\mathrm{kg} \mathrm{ha}^{-1} \mathrm{DM}\right)(\mathrm{SEM}=341.9)$} \\
\hline 30 & $921.79^{\mathrm{Bb}}$ & $1470.88^{\mathrm{ABb}}$ & $1179.56^{\mathrm{ABc}}$ & $2055.16^{\mathrm{Ab}}$ & $2131.58^{\mathrm{Ab}}$ \\
45 & $2860.86^{\mathrm{Ba}}$ & $3197.23^{\mathrm{Ba}}$ & $2715.57^{\mathrm{Bb}}$ & $3476.74^{\mathrm{Ba}}$ & $5342.24^{\mathrm{Aa}}$ \\
60 & $3347.41^{\mathrm{Ba}}$ & $3782.91^{\mathrm{Ba}}$ & $3978.62^{\mathrm{Ba}}$ & $4244.82^{\mathrm{Ba}}$ & $6510.32^{\mathrm{Aa}}$ \\
\hline \multicolumn{5}{c}{${\text { Stem mass }\left(\mathrm{kg} \mathrm{ha}^{-1} \mathrm{DM}\right)(\mathrm{SEM}=413.24)}$} \\
\hline 30 & $840.34^{\mathrm{Ac}}$ & $769.97^{\mathrm{Ab}}$ & $574.86^{\mathrm{Ab}}$ & $1139.89^{\mathrm{Ac}}$ & $1141.26^{\mathrm{Ac}}$ \\
45 & $2291.45^{\mathrm{ABb}}$ & $1938.48 \mathrm{~A}^{\mathrm{Bab}}$ & $1553.09^{\mathrm{Bb}}$ & $2748.51^{\mathrm{ABb}}$ & $4025.03^{\mathrm{Ab}}$ \\
60 & $6117.12^{\mathrm{Aa}}$ & $2822.92^{\mathrm{Da}}$ & $3603.05^{\mathrm{CDa}}$ & $4601.16^{\mathrm{BCa}}$ & $5745.27^{\mathrm{ABa}}$ \\
\hline 30 & $1.13^{\mathrm{Ba}}$ & $1.82^{\mathrm{Aa}}$ & $1.86^{\mathrm{Aa}}$ & $1.76^{\mathrm{Aa}}$ & $1.79^{\mathrm{Aa}}$ \\
45 & $1.23^{\mathrm{Aa}}$ & $1.61^{\mathrm{Aa}}$ & $1.66^{\mathrm{Aa}}$ & $1.25^{\mathrm{Aab}}$ & $1.32^{\mathrm{Aab}}$ \\
60 & $0.58^{\mathrm{Bb}}$ & $1.31^{\mathrm{Aa}}$ & $1.13^{\mathrm{ABb}}$ & $0.93^{\mathrm{ABb}}$ & $1.16^{\mathrm{Ab}}$ \\
\hline
\end{tabular}

SEM (standard error of mean). Means followed by distinct letters, upper case in the row and lowercase in the column, differ by Tukey test $(\mathrm{P}<0.05)$.

Those plants handled with defoliation frequencies of 30 and 45 days displayed leaf blade stem ratio higher than those cut at 60 days intervals, except Marandu, which was not affected $(p>0.05)$ by the cutting intervals. We could not observe any difference among the cultivars for this parameter at the cutting interval of 45 days. Even though, at the 30 days interval, cv Basilisk obtained the lowest leaf blade stem ratio in comparison with the others. At the 60 days cutting interval, this ratio was higher for cvs. Marandu and Xaraés and lower for cv. Basilisk. Cvs. Mulato I and Piatã did not differ from the others (Table 5).

Forage accumulation rate (FAR) did not differ according to the cutting intervals in the cvs. Marandu and Piatã. In the other cvs., FAR was higher at the cutting intervals of 45 and 60 days, in comparison with the 30 days aftermath (Table 6). Xaraés grass displayed a higher FAR than the others at all cutting intervals, but the 30 days one. At this interval, it did not differ from cvs. Piatã and Marandu. 
Table 6. Forage accumulation rate, leaf blade and stem in Urochroa cultivars under different defoliation frequencies

\begin{tabular}{|c|c|c|c|c|c|}
\hline \multirow{2}{*}{ Cut interval (day) } & \multicolumn{5}{|c|}{ Cultivar } \\
\hline & Basilisk & Marandu & Mulato I & Piatã & Xaraés \\
\hline & \multicolumn{5}{|c|}{ Forage accumulation rate $\left(\mathrm{kg} \mathrm{ha}^{-1} \mathrm{day}^{-1} \mathrm{DM}\right)(\mathrm{SEM}=11.15)$} \\
\hline 30 & $58.74^{\mathrm{Bb}}$ & $74.70 \mathrm{~A}^{\mathrm{Ba}}$ & $58.48^{\mathrm{Bb}}$ & $106.50^{\mathrm{Aa}}$ & $109.09^{\mathrm{Ab}}$ \\
\hline 45 & $114.50^{\mathrm{Ba}}$ & $114.13^{\mathrm{Ba}}$ & $94.86^{\mathrm{Bab}}$ & $138.34^{\mathrm{Ba}}$ & $208.17^{\mathrm{Aa}}$ \\
\hline \multirow[t]{2}{*}{60} & $157.75^{\mathrm{Ba}}$ & $110.10^{\mathrm{Ba}}$ & $126.36^{\mathrm{Ba}}$ & $147.44^{\mathrm{Ba}}$ & $204.26^{\mathrm{Aa}}$ \\
\hline & \multicolumn{5}{|c|}{ Leaf blade accumulation rate $\left(\mathrm{kg} \mathrm{ha}^{-1}\right.$ day $\left.^{-1} \mathrm{DM}\right)(\mathrm{SEM}=6.22)$} \\
\hline 30 & $30.73^{\mathrm{Bb}}$ & $49.03^{\mathrm{Ba}}$ & $39.32^{\mathrm{Ba}}$ & $68.51^{\mathrm{Aa}}$ & $71.05^{\mathrm{Ab}}$ \\
\hline 45 & $63.58^{\mathrm{Ba}}$ & $71.05^{\mathrm{Ba}}$ & $60.35^{\mathrm{Ba}}$ & $77.26^{\mathrm{Ba}}$ & $118.72^{\mathrm{Aa}}$ \\
\hline 60 & $55.79^{\mathrm{Ba}}$ & $63.05^{\mathrm{Ba}}$ & $66.31^{\mathrm{Ba}}$ & $70.75^{\mathrm{Ba}}$ & $108.50^{\mathrm{Aa}}$ \\
\hline \multicolumn{6}{|c|}{ Stem accumulation rate $\left(\mathrm{kg} \mathrm{ha}^{-1}\right.$ day $\left.^{-1} \mathrm{DM}\right)(\mathrm{SEM}=6.00)$} \\
\hline 30 & $28.01^{\mathrm{Ab}}$ & $25.67^{\mathrm{Aa}}$ & $19.16^{\mathrm{Ab}}$ & $38.00^{\mathrm{Ab}}$ & $38.04^{\mathrm{Ab}}$ \\
\hline 45 & $50.92^{\mathrm{ABb}}$ & $43.08^{\mathrm{Ba}}$ & $34.52^{\mathrm{Bb}}$ & $61.08^{\mathrm{Ba}}$ & $89.45^{\mathrm{Aa}}$ \\
\hline 60 & $101.95^{\mathrm{Aa}}$ & $47.05^{\mathrm{Ca}}$ & $60.05^{\mathrm{BCa}}$ & $76.69^{\mathrm{Ba}}$ & $95.76^{\mathrm{Aa}}$ \\
\hline
\end{tabular}

SEM (standard error of mean). Means followed by distinct letters, upper case in the row and lowercase in the column, differ by Tukey test $(\mathrm{P}<0.05)$.

The cutting interval did not affect $(p>0.05)$ the leaf blade accumulation rate (LBAR) at any cutting interval in the varieties Marandu, Mulato I. and Piatã. In the cvs. Basilisk and Xaraés, LBAR was lower at the 30 days aftermath, than at the other cutting intervals. At all cutting intervals, cv. Xaraés displayed higher LBAR than the other cultivars. Even though, it did not differ from Piatã grass at 30 days of regrowth.

In the variety Marandu, the cutting interval did not affect $(p>0.05)$ the stem accumulation rate (SAR) at any cutting interval. In the other cultivars, SAR was directly proportional with the extension of the cutting interval. As comparing the different cvs., SAR displayed no significant difference just at the 30 days of regrowth. At the other cutting intervals, cvs. Xaraés and Basilisk displayed higher values than the remaining varieties.

\section{Discussion}

Our results confirm that, as the cutting interval was growing, we observed an increase in the leaf blade length, stem diameter, and canopy height. These results are due to the longer time of free growth of the plant, which allowed a higher development of the tillers, and subsequently, of the stems, and leaf blades. According to Skinner \& Nelson (1995), the length of the leaf blade depends on the length of the pseudostem which determines the distance, that the blade needs to range to emerge. As extending the cutting interval, there is an extension of the pseudostem, and the distance run by the leaf is higher, which causes the elongation of the leaf blades. It is worth to highlight that, even if we did not assess the length of the pseudostem, its growth directly relates to the development of the stem. Medica et al. (2017) observed that plants become higher as submitted to longer cutting intervals, due to the higher interspecific competition for the sunlight. This competition causes the elongation of the stem to expose the leaves to the higher layer of the pasture.

The lack of influence of the cutting interval on the width of the leaf blade suggests that the growth of the leaves occurs more on the length, rather than the width. Pereira et al. (2019) 
studied the morphogenic and structural features of tropical forage crops in the Brazilian semiarid region. The authors confirmed that the period of aftermath did not affect the length of the leaf blade of the Buffelgrass, and Massaigrass. These results corroborate those we obtained in this study.

The understatement on these morphological features is of the highest relevance. The leaf blade is the main component of the forage mass and the primary component of the active photosynthetic tissue. It is responsive for the growth of the plant, has a high nutritional value, which is the most preferred by the ruminants (Alexandrino et al. 2004). It is crucial to point out, the size of the leaf can affect the foraging of the animals: broader and longer leaf blades can ease this process (Migliorini et al. 2012), reducing the grazing time.

The height of the pasture can be used as a field criterium for the pasture handling, as it has a strong correlation with the sunlight interception performed by the canopy (SI), and serves as a reference for the interruption of the regrowth (2007). The height that corresponds to 95\% SI is specific for any forage plant and corresponds to $19 \mathrm{~cm}$ for cv. Basilisk (Braga et al. 2009); 24,1 cm for cv. Marandu (Trindade et al. 2007); $30 \mathrm{~cm}$ for cv. Mulato I (Silveira et al. 2016); and 42 , and $47 \mathrm{~cm}$ for the cvs. Piatã and Xaraés, respectively (Janusckiewicz et al. 2015). Our results suggest that, even at the shortest cutting interval (30 days) of our experiment, the regrowth time is still long for the forage harvest. Therefore, the forage grasses shall be used with shorter times of regrowth, allowing a higher number of cuttings, or stocking periods.

Martuscello et al. (2015) corroborate our results on the leaves number. These authors report, leaves number is genetically determined, specific for each species or cultivar and cannot be naturally modified. Even the same, this characteristic can respond to variations of the climate, and the soil, with a reduction of the number of live leaves under stress conditions. According to Pena et al. (2009), as the plant reaches the maximum live leaves of the tiller, there is an equilibrium between the appearance and senescence of the leaves. As a new leaf rises, there is the senescence of an old one, in a relatively uniform number of leaves per tiller. Santos et al. (2010) studied pastures of basilisk grass at 73, 95 and 116 days. In their study, the authors find respectively, 4.53; 4.13, and 4.80 live leaves tiller $^{-1}$, confirming that this characteristic is sTable.

In our study, we also observed, that the increase of the cutting interval directly influenced the forage mass. We observed higher masses at longer cutting intervals, which is associated with the longest available time for the forage accumulation. Bauer et al. (2011) studied forages of the genus Urochroa and observed, at 30 days aftermath, 4,215 kg ha-1 DM of forage mass for the cultivar Mulato I, and higher than $3,500 \mathrm{~kg} \mathrm{ha}^{-1} \mathrm{DM}$ for the varieties Xaraés and Basilisk. These results are higher than those found in this study. We suppose, the results obtained by Bauer et al. (2011) could have been obtained due to the application of $50 \mathrm{~kg} \mathrm{ha}^{-1}$ Nitrogen every 30 days. The total forage mass represents the jointed mass of the fractions leaf, and stem. LBAR, SAR, and their respective masses have similar behavior to what we observed in the mass of the total forage.

It is essential to point out that, even if the forage mass accumulated, as the cutting interval 
increased from 30 to 60 days, stem mass became more and more significant in the total forage mass. The increase of the stem mass is especially for cv. Basilisk. At the 60 days cutting interval, its SAR was almost twice higher than the LBAR, which caused a reduction of the leaf stem ratio at this same cutting interval (age). According to Oliveira et al. (2019), the cut-off interval of 45 days, the cultivars of Panicum maximum have shown satisfactory yield, and the smaller cut interval provides a reduction in canopy height and stem thickness.

In grasses of erect growth, such as the cultivars that have been studied, except cv. Basilisk (creeping growth), the elongation of the stem interferes on the structure of the pasture, compromising the efficiency of stocking due to the decrease of the leaf stem ratio (Rodrigues et al. 2008). According to Bhering et al. (2008), among the disorders in the structure of the canopy, the development, and elongation of the stem is one of those that requires special attention, for it compromises the qualitative aspects of the forage, as the content of dry matter, raw protein, neutral detergent fibers, and in vitro digestibility of the organic matter.

Stem masses were high in all cultivars, as compared with the values described by Emerenciano Neto et al. (2013) for the cvs. Marandu and Piatã $\left(594,7\right.$ e 477,7 kg ha ${ }^{-1} \mathrm{DM}$, respectively), except cv. Mulato, which approximated to these values as cut at 30 of regrowth. The results depict that the high amount of stems in the pasture may be associated with the handling based on fixed days of regrowth, and not on the assessment of the heights before stocking.

Besides the excessive accumulation of stems as the age of the plants is growing, Emerenciano Neto et al. (2017) point out that, the higher the interval between the cuts, the higher the chances to lose the accumulated forage due to the senescence of the leaves. The senescence of the leaves results in low efficiency (of the pasture management), because the produced forage is not being harvested, or stocked.

According to the results we obtained we shall infer that these are directly associated with the morphological features of each cultivar. According to Silveira et al. (2010), Xaraés grass is larger than the rest of the cultivars of the genus Urochloa. For this reason, its leaf development is higher, with a longer and more developed stem. For these reasons, this variety is higher, and has higher production of dry matter, as discussed earlier. According to the authors, the time required to nter the reproductive phase of the Xaerés grass is longer: approximatively twice more than the cvs. Piatã, Marandu and Basilisk, which have an earlier flowering, providing a higher accumulation of forage, for a longer time.

Lara \& Pedreira (2011) studied five different cultivars of Urochloa. Their results pointed out, that cv. Xaraés is more productive than cvs. Marandu e Basilisk, due to its morphogenic, and structural features. These results corroborate those we obtained in the present study. Our results highlight the higher photosynthetic and productive capacity of the cv. Xaraés, as, under the same conditions of handling, it accumulated more forage than the other cultivars studied.

\section{Conclusions}

Urochloa grasses should be managed with defoliation frequencies of up to 45 days. From this 
age on, the accumulation of stem occurs in a quite accentuated way, leading to massive qualitative losses. The Xaraés grass was the most productive among the cultivars, with high participation of leaf blades in the forage mass, being able to be indicated for intensive pasture production systems.

\section{Acknowledgement}

This study was financed in part by the Coordenação de Aperfeiçoamento de Pessoal de Nível Superior - Brasil (CAPES) - Finance Code 001.

\section{References}

Alexandrino, E., Gomide, C. A. M., Cândido, M. J. D., \& Gomide, J. A. (2005). Rest period, canopy structural traits and steer body weight gain on intermittently grazed mombaçagrass pasture. Revista Brasileira de Zootecnia, 34, 2174-2184.

https://doi.org/10.1590/S1516-35982005000700003

Alexandrino, E., Nascimento Júnior, D., Mosquim, P. R., Regazzi, A. J., \& Rocha, F. C. (2004). Morphogenesis and structural characteristics of regrowth of Brachiaria brizantha cv.marandu assigned to three nitrogen levels. Revista Brasileira de Zootecnia, 33, 1372-1379. https://doi.org/10.1590/S1516-35982004000600003

Bauer, M. O., Pacheco, L. P. A., Chichorro, J. F., Vasconcelos, L. V., \& Pereira, D. F. C. (2011). Herbage yield and structural characteristics of five Brachiaria genus forages under intermittently defoliation sward. Ciência Animal Brasileira, 12, 17-25.

https://doi.org/10.5216/cab.v12i1.4817

Bhering, M., Cabral, L. S., Abreu, J. G., Souza, A. L., Zervoudakis, J. T., Rodrigues, R. C., ... Oliveira, I. S. (2008). Agronomical characteristics of elephant grass variety "roxo" in different cut ages in Cuiabana Lowlands. Revista Brasileira de Saúde e Produção Animal, 9, 384-396.

Braga, G., Portela, J. N., Pedreira, C. G. S., Leite, V. B. O., \& Oliveira, E. A. (2009). Herbage yield in Signalgrass pastures as affected by grazing management. South African Journal of Animal Science, 39,130-132. https://doi.org/10.4314/sajas.v39i1.61168

Cutrim Júnior, J. A. A., Cândido, M. J. D., Valente, B. S. M., Carneiro, M. S. S., Carneiro, H.A.V., \& Cidrão, P. M. L. (2010). Biomass flow of the tanzânia grass under three defoliation frequencies and two postgrazing residues. Revista Brasileira de Saúde e Produção Animal, 11, 618-629.

Emerenciano Neto, J. V., Difante, G. S., Lana, A. M. Q., Campos, N. R. F., Veras, E. L. L., \& Moraes, J. D. (2017). Sward structure and herbage accumulation of massai guineagrass pastures managed according to pre-grazing heights, in the Northeast of Brazil. Journal of Agricultural Science, 9, 155-163. https://doi.org/10.5539/jas.v9n4p155

Emerenciano Neto, J. V., Difante, G. S., Montagner, D. B., Bezerra, M. G. S., Galvão, R. C. P., \& Vasconcelos, R. I. G. (2013). Sward structural characteristics and herbage accumulation in tropical grasses, under intermittent stocking and sheep grazed. Bioscience Journal, 29, 
962-973.

Empresa Brasileira de Pesquisa Agropecuária - EMBRAPA. Centro Nacional de Pesquisa de Solos. Sistema Brasileiro de Classificação de solos. 2.Ed. Rio de Janeiro, Embrapa, 2006, $306 \mathrm{p}$.

Euclides, V. P. B., Valle, C. B., Macedo, M. C. M., Almeida, R. G., Montagner, D. B., \& Barbosa, R. A. (2010). Brazilian scientific progress in pasture research during the first decade of XXI century. Revista Brasileira de Zootecnia, 39, 151-168.

https://doi.org/10.1590/S1516-35982010001300018

Ferreira, D. F. (2011). Sisvar, a computer statistical analysis system. Ciência $e$ Agrotecnologia, 35, 1039-1042. https://doi.org/10.1590/S1413-70542011000600001

Janusckiewicz, E. R., Chiarelli, C. B., Cunha Neto, D. C., Raposo, E., \& Ruggieri, A. C. (2015). How the intercropping between corn and palisade grass cultivars affects forage production and pastures characteristics under grazing. American Journal of Plant Sciences, 6, 1475-1482. https://doi.org/10.4236/ajps.2015.69146

Lara, M. A. S., \& Pedreira, C. G. S. (2011). Structural and morphogenetic responses of swards of Brachiaria species to defoliation intensity. Pesquisa Agropecuária Brasileira, 46, 760-767. https://doi.org/10.1590/S0100-204X2011000700012

Martuscello, J. A., Silva, L. P., Cunha, D. N. F. V., Batista, A. C. S., Braz, T. G. S., \& Ferreira, P. S. (2015). Nitrogen fertilization in massaigrass, production and morphogenesis. Ciência Animal Brasileira, 16, 1-13. https://doi.org/10.1590/1089-68916i118730

Medica, J. A. S., Reis, N. S., \& Santos, M. E. R. (2017). Morfologic characterization on marandu grass pastures submitted to defoliation frequencies and fertilization levels. Ciência Animal Brasileira, 18, 1-13. https://doi.org/10.1590/1089-6891v18e-40460

Migliorini, F., Soares, A. B., Pontes, L.S., Silveira, A. F., \& Ferrazza, J. M. (2012). Defoliation frequency and severity of alexandergrass pasture under grazing intensities in continuous stocked by goats. Synergismus scyentifica UTFPR, 7, 1-4.

Oliveira, J. S., Emerenciano Neto, J. V., Difante, G. S., Lista, F. N., Santos, R. S., Bezerra, J. D. V., ... Ribeiro, J. S. M. (2019). Structural and productive features of Panicum cultivars submitted to different rest periods in the irrigated semiarid region of Brazil. Bioscience Journal, 35, 682-690. https://doi.org/10.14393/BJ-v35n3a2019-36402

Pena, K. S., Nascimento Júnior, D., Silva, S. C., Euclides, V. P. B., \& Zanine, A. M. (2009). Morphogenic and structural characteristics and herbage accumulation of Tanzania grass submitted to two cutting heights and three intervals. Revista Brasileira de Zootecnia, 38, 2127-2136. https://doi.org/10.1590/S1516-35982009001100009

Pereira, G. F., Emerenciano Neto, J. V., Difante, G. S., Assis, L. C. S. L. C., \& Lima, P. O. (2019). Morphogenic and structural characteristics of tropical forage grasses managed under different regrowth periods in the Brazilian semi-arid region. Semina: Ciências Agrárias, 40, 283-292. https://doi.org/10.5433/1679-0359.2019v40n1p283 
Rodrigues, R. C., Mourão, G. B., Brennecke, K., Luz, P. H. C., \& Herling, V. R. (2008). Dry matter production, leaf/stem ratio and growth indexes of palisade grass (Brachiaria brizantha cv. Xaraés), cultivated with different rate combinations of nitrogen and potassium. Revista Brasileira de Zootecnia, 37, 394-400. https://dx.doi.org/10.1590/S1516-35982008000300003

Santos, M. E. R., Fonseca, D. M, Balbino, E. M., Silva, S. P., Monnerat, J. P. I. S., \& Gomes, V. M. (2010). Structural characteristics of vegetative and reproductive tillers on diferred signalgrass pastures. Ciência Animal Brasileira, 11, 492-502.

https://doi.org/10.5216/cab.v11i3.4957

Santos, M. E. R., Gomes, V. M., Fonseca, D. M., Albino, R. L., Silva, S. P., \& Santos, A. L. (2011). Number of tillers of Brachiaria grass in continuous stocking regime. Acta Scientiarum. Animal Sciences 33, 1-7. https://doi.org/10.4025/actascianimsci.v33i1.10440

Silva, S. C., \& Nascimento Júnior, D. (2007). Avanços na pesquisa com plantas forrageiras tropicais em pastagens: características morfofisiológicas e manejo do pastejo. Revista Brasileira de Zootecnia, 36, 121-138. https://doi.org/10.1590/S1516-35982007001000014

Silveira, M. C. T., Nascimento Júnior, D., Rodrigues, C. S., Pena, K. S., Souza Júnior, S. J., Barbero, L. M., Limão, V. A., Euclides, V. P. B., \& Silva, S.C. (2016). Forage sward structure of mulato grass (Brachiaria hybrid ssp.) subjected to rotational stocking strategies. Australian Journal of Crop Science, 10, 864-873.

https://doi.org/10.21475/ajcs.2016.10.06.p7568

Silveira, M. C. T., Nascimento Júnior, D., Silva, S. C., Euclides, V. P. B., Montagner, D. B., Sbrissia, A. F., ... Vilela, H. H. (2010). Morphogenetic and structural comparative characterization of tropical forage grass cultivars under free growth. Scientia Agricola, 67, 136-142. https://doi.org/10.1590/S0103-90162010000200002

Skinner, R. H., \& Nelson, C. J. (1995). Elongation of the grass leaf and its relationship phillochron. Crop Science, 35, 4-10.

https://doi.org/10.2135/cropsci1995.0011183X003500010002x

Trindade, J. K., Silva, S. C., Souza Júnior, S. J., Giacomini, A. A., Zeferino, C. V., Guarda, V. D. A., \& Carvalho, P. C. F. (2007). Morphological composition of the herbage consumed by beef cattle during the grazing down process of marandu palisadegrass subjected to rotational strategies. Pesquisa Agropecuária Brasileira, 42, 883-890.

https://doi.org/10.1590/S0100-204X2007000600016

\section{Copyright Disclaimer}

Copyright for this article is retained by the author(s), with first publication rights granted to the journal.

This is an open-access article distributed under the terms and conditions of the Creative Commons Attribution license (http://creativecommons.org/licenses/by/4.0/). 